Indonesian Journal of Cardiology

Indonesian J Cardiol 2017:38:202-6

pISSN: 0I 26-3773 / elSSN: 2620-4762

\title{
Effect of Myocardial Fibrosis on Left Ventricular Function in Rheumatic Mitral Stenosis: A Preliminary Study with Cardiac Magnetic Resonance
}

\author{
Elen Elen, Celly A Atmadikoesoemah, Manoefris Kasim
}

Department of Cardiology and Vascular Medicine, Faculty of Medicine, Universitas Indonesia National Cardiovascular Center Harapan Kita, Jakarta, Indonesia
Background: Left ventricular (LV) dysfunction was frequently found in rheumatic mitral stenosis. Myocardial fibrosis had been revealed in rheumatic heart disease and could be associated with LV dysfunction. We evaluate myocardial fibrosis profile related to LV function in rheumatic mitral stenosis with cardiac magnetic resonance (CMR).

Methods: Eighteen patients with severe rheumatic mitral stenosis without history of coronary artery disease or its risk factors underwent I.5T CMR examination. LV ejection fraction (LVEF), right ventricular ejection fraction (RVEF), myocardial fibrotic tissue were evaluated with CMR. Other hemodynamic data was derived from echocardiography results.

Results: These patients ( $40.4 \pm 10.5$ years old, $72.2 \%$ female, $66.7 \%$ atrial fibrillation) had LVEF of $50.9 \pm 15.9 \%$ and RVEF of $37.7 \pm 13.9 \%$. Volume of fibrotic tissue in these patients were 16.6 (5.5-55.8)\%. In multivariate analysis, volume of fibrotic tissue was a significant predictor of LVEF that myocardial fibrotic tissue of $1 \%$ was associated with LVEF reduction of $0.87 \%$ ( $95 \% \mathrm{Cl} 0.5 \mathrm{I} \%-\mathrm{I} .24 \%)$.

Conclusion: LV function was determined by the extent of myocardial fibrosis in rheumatic mitral stenosis.

(Indonesian J Cardiol. 2017;38:202-6)

Keyword: myocardial fibrosis, left ventricular dysfunction, rheumatic mitral stenosis 


\title{
Pengaruh Fibrosis Myocardium terhadap Fungsi Ventrikel Kiri pada Stenosis Mitral Rematik: Studi Preeleminer dengan Cardiac Magnetic Resonance
}

\author{
Elen Elen, Celly A Atmadikoesoemah, Manoefris Kasim
}

Latar Belakang: Disfungsi ventrikel kiri (LV) sering ditemukan pada mitral stenosis rematik. Fibrosis miokardium ditemukan pada penyakit jantung rematik. Fibrosis miokardium pada penyakit jantung rematik juga dihubungkan dengan disfungsi LV. Kami mengevaluasi profil fibrosis miokardium yang berhubungan dengan fungsi LV pada mitral stenosis rematik dengan cardiac magnetic resonance (CMR).

Metode: Dilakukan pemeriksaan 1.5T CMR pada delapanbelas pasien dengan mitral stenosis rematik berat tanpa riwayat penyakit jantung koroner atau faktor resikonya. Fraksi ejeksi LV (LVEF), fraksi ejeksi RV (RVEF), dan jaringan fibrotik miokardium dievaluasi menggunakan CMR. Data hemodinamik lainnya didapatkan dari pemeriksaan ekokardiografi.

Hasil: Pasien tersebut ( $40.4 \pm 10.5$ tahun, $72.2 \%$ perempuan, $66.7 \%$ fibrilasi atrium) memiliki LVEF $50.9 \pm 15.9 \%$ dan RVEF $37.7 \pm 13.9 \%$. Volume jaringan fibrotic pada pasien tersebut adalah $16.6(5.5-55.8) \%$. Dalam analisis multivariat, volume jaringan fibrotic adalah prediktor LVEF yang signifikan yaitu 1\% jaringan fibrotic miokardium dihubungkan dengan menurunan LVEF sebesar 0.87\% (95\% CI 0.51\%-1.24\%). Kesimpulan: Fungsi LV dipengaruhi seberapa besar fibrosis miokardium pada mitral stenosis rematik

(Indonesian J Cardiol. 2017;38:202-6)

Kata Kunci: fibrosis miokardium, disfungsi ventrikel kiri, mitral stenosis rematik

Departemen Kardiologi dan Kedokteran Vaskular, Fakultas Kedokteran, Universitas Indonesia. Pusat Jantung Nasional Harapan Kita, Jakarta, Indonesia

\section{Correspondence:}

dr. Celly Atmadikoesoemah, Sp.JP, Department of Cardiology and Vascular Medicine, Faculty of Medicine, Universitas Indonesia. National Cardiovascular Center Harapan Kita, Jakarta, Indonesia. Email: idocelly@gmail.com

\section{Background}

Rheumatic heart disease (RHD) is a chronic inflammatory disease that also involving myocardium. Left ventricular (LV) dysfunction was found in about one-fourth of patients with rheumatic mitral stenosis. Many theories were proposed as the causes of the LV dysfunction. Myocardial fibrosis had been revealed in rheumatic heart disease and could be associated with LV dysfunction. ${ }^{1}$ This study aimed to evaluate myocardial fibrosis profile related to left ventricular (LV) function in rheumatic mitral stenosis with cardiac magnetic resonance (CMR). 


\section{Methods}

\section{Study population}

Eighteen patients with severe rheumatic mitral stenosis without history of coronary artery disease or its risk factors were prospectively enrolled in the period from August 2015 to March 2016 in National Cardiovascular Center Harapan Kita, Jakarta-Indonesia.

\section{Cardiac magnetic resonance examination}

Cardiac magnetic resonance examination was done with using 1.5T MR scanner (Achieva, Philips Healthcare, Best, The Netherlands) with 32-channel cardiac coil. LV ejection fraction (LVEF) and right ventricular ejection fraction (RVEF) were quantified from cineCMR images using a sense balanced turbo field echo sequence with breath-hold. Myocardial fibrotic tissue were evaluated with late gadolinium enhancement (LGE) images. LGE images were done by using gapless whole heart coverage of short axis slices, 2-chamber and 4-chamber long axis slices and using gadobutrol (Gadovist $^{\circledR}$, Bayer, Leverkusen, Germany) with dose of $0.1 \mathrm{mmol} / \mathrm{kg}$ body weight, then the image acquisition was done 10 minutes after contast administration.

LVEF and RVEF were derived by end diastolic volume and end systolic volume. Endocardial borders were manually traced at end-diastole and end-systole phases from short axis slices. The papillary muscles were included as part of the LV cavity volume. LGE was quantified by a manual contouring method and reported as a percentage of total LV mass. Postprocessing analysis were done by using commercial software (CVI42®, Circle, Calgary, Canada).

\section{Other hemodynamic data}

Mitral valve area, mean mitral valve gradient, severity of pulmonary hypertension were obtained by echocardiography examination that were done 1-2 weeks before CMR examination.

\section{Statistical analysis}

Statistical analysis was performed using dedicated software (IBM SPSS Statistics, version 22). Shapiro-Wilk test and histograms were preliminarily performed to assess distribution of quantitative data. For numerical data, normal distribution data were expressed as mean \pm SD while abnormal distribution data were expressed as median (minimum-maximum value). For categorical data, the proportion were expressed as percentage. The differences of proportion were analysed with Fischer's exact test. The bivariate correlations were analyzed by Pearson correlation if the data were normally distributed and by Spearman correlation if the data were abnormally distributed. The multivariate analysis for LVEF was done by linier regression analysis. A value of $\mathrm{p}<0.05$ was considered significant.

\section{Results}

These patients $(40.4 \pm 10.5$ years old, $72.2 \%$ female, $66.7 \%$ atrial fibrillation) had mitral valve area of $0.7 \pm 0.2 \mathrm{~cm}^{2}$, mean mitral valve gradient of $12.6 \pm 4.1$ $\mathrm{mmHg}$. Severe pulmonary hypertension was observed in $66.7 \%$ patients. From CMR analysis of these patients, LVEF was $50.9 \pm 15.9 \%$ while RVEF was $37.7 \pm 13.9 \%$.

Myocardial fibrotic tissue was found in all patients with distribution as follows: at basal and mid segments $100 \%$, at apical segments $55.6 \%$. Fibrotic tissue at apical segments was observed more often in patients with LVEF $<50 \%$ ( $\mathrm{p} 0.02$ ). Fibrotic tissue was found at anterior $77.8 \%$, septal $88.9 \%$, lateral $88.9 \%$, and inferior $94.4 \%$, with predilection at inferior and anterior LV-RV junction (Figure 1).

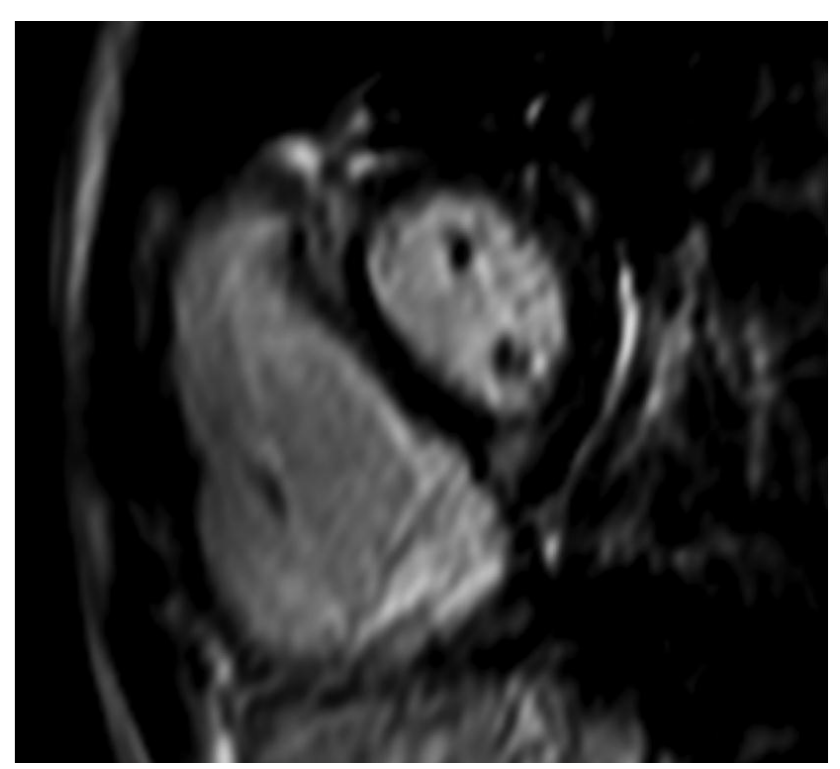

Figure 1. Myocardial fibrotic tissue in severe rheumatic mitral stenosis with predilection at inferior and anterior LV-RV junction 
Table 1. Bivariate analysis for left ventricular ejection fraction

\begin{tabular}{lcc}
\hline Variabel & $\mathrm{r}$ & $\mathrm{p}$ \\
\hline Age (years old) & 0.05 & 0.83 \\
Gender & & 0.71 \\
Heart rhythm - AF & & 0.08 \\
Mitral valve area $\left(\mathrm{cm}^{2}\right)$ & -0.16 & 0.52 \\
Pulmonary hypertension & & 0.82 \\
RVEF (\%) & 0.49 & 0.04 \\
Volume of fibrotic tissue (\%) & -0.95 & $<0.001$ \\
\hline
\end{tabular}

$\mathrm{AF}=$ atrial fibrillation, $\mathrm{RVEF}=$ right ventricular ejection fraction

\section{Discussion}

Chronic rheumatic heart disease had a persistent inflammatory process in the heart tissue in the absence of the infectious agent. The inflammatory process can be characterized by typical Aschoff bodies and has a predilection for the heart valves. It is characterized by deforming fibrotic valvular disease, especially as mitral stenosis. ${ }^{2}$ In addition to affecting the cardiac valves, rheumatic heart disease is a pancarditis affecting to various

Table 2. Multivariate analysis for left ventricular ejection fraction

\begin{tabular}{lcccc}
\hline Variable & $\mathrm{B}$ & $\beta$ & $\mathrm{p}$ & $\begin{array}{c}95 \% \\
\text { Confidence interval }\end{array}$ \\
\hline (Constant) & 66.39 & & $<0.001$ & $49.02-83.78$ \\
Volume of fibrotic tissue & -0.87 & -0.81 & $<0.001$ & $-1.24--0.51$ \\
Heart rhythm - AF & -2.41 & -0.07 & 0.61 & $-12.42-7.60$ \\
RVEF & 0.13 & 0.11 & 0.45 & $-0.23-0.49$ \\
\hline
\end{tabular}

$\mathrm{AF}=$ atrial fibrillation, $\mathrm{RVEF}=$ right ventricular ejection fraction

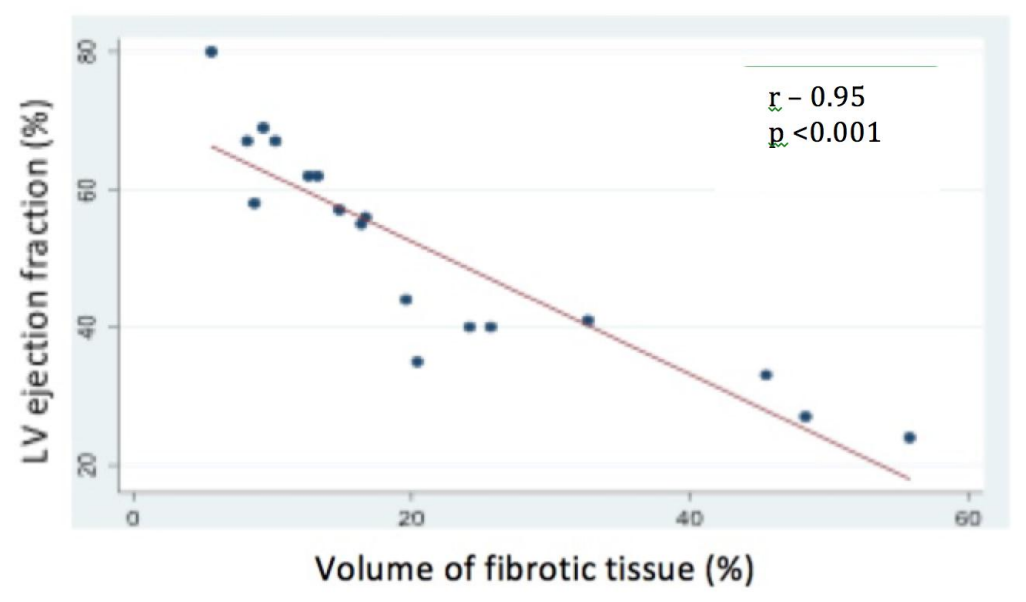

Figure 2. Correlation between volume of fibrotic tissue and left ventricular ejection fraction

Volume of fibrotic tissue in these patients were 16.6 (5.5-55.8)\%. In bivariate analysis, volume of fibrotic tissue had strong negative correlation with LVEF ( $\mathrm{r}$ $-0.95, \mathrm{p}<0.001)$ as seen in Table 1 and Figure 2. By multivariate analysis, volume of fibrotic tissue was a significant predictor of LVEF. Myocardial fibrotic tissue volume of $1 \%$ was associated with LVEF reduction of $0.87 \%$ (95\% CI 0.51-1.24\%). degrees the endocardium, myocardium, and pericardium. In some cases, rheumatic myocarditis results in cardiac dilation and progressive heart failure. LV dysfunction was found in one fourth of patients with pure mitral stenosis. Several pathophysiologic theories of LV dysfunction in rheumatic MS has been proposed, such as: underflow preload, altered interaction between right and left ventricles, rhythm disturbance, and myocardial fibrosis. ${ }^{1}$ 
Myocardial fibrosis is a common sequelae of rheumatic fever and can be associated with LV dysfunction. Interstitial fibrosis and myocyte disarray were found as microscopic findings of myocardium in delayed-enhanced segments by CMR, while no evidence of myocardial fibrosis was found in nondelayed-enhanced segments. ${ }^{3}$ Most RHD patients with severe LV dysfunction but no evidence of myocardial fibrosis in LGE-CMR could have LV function improvement after valve surgery. ${ }^{4}$

This study revealed myocardial fibrotic tissue in rheumatic severe mitral stenosis patients. The distribution was more rare in apical segments rather than basal-mid segments (closer segments to mitral valve). Patient with LV dysfunction had more fibrotic tissue in apical segments, this could indicate more severity of the disease. The fibrotic tissue was distributed evenly at anterior, septal, lateral, and inferior segments. Volume of fibrotic tissue negatively correlated with LV systolic function. This quantification of myocardial fibrotic tissue in rheumatic mitral stenosis may contribute as prognostic factor prior to valve surgery.

\section{Conclusion}

LV function in patients with rheumatic mitral stenosis was determined by the extent of myocardial fibrosis.

\section{List of abbreviations}

CMR: Cardiac Magnetic Resonance

LGE: Late Gadolinium Enhancement
LV: Left Ventricle

LVEF: Left Ventricular Ejection Fraction

RHD: Rheumatic Heart Disease

RVEF: Right Ventricular EJection Fraction

\section{Ethical Clearance}

\section{Publication approval}

The publication of this article has been approved by every party.

\section{Conflict of interest}

None Declared

\section{References}

1. Gaasch WH, Folland ED. Left ventricular function in rheumatic mitral stenosis. Eur Heart J 1991; 12 Suppl B: 66-9.

2. Rashed M, Nagm M, Galal M, Ragab N. Clinical and histopathologic study of surgically excised mitral valves in children. Inter J Path. 2006;5:1-7.

3. Choi EY, Yoon SJ, Lim SH, Choi BW, Ha JW, Shin DH, et al. Detection of myocardial involvement of rheumatic heart disease with contrast-enhanced magnetic resonance imaging. Int J Cardiol. 2006; 113:e36-e38.

4. Gopalakhrishnan A, Selvam SP, Kapilamoorthy TR, Kumar VKA. Cardiac MRI in rheumatic heart disease patients with significant left ventricular dysfunction. Indian Heart J. 2014; 66:s141-s142. 